\title{
A globalização e as universidades latino-americanas
}

\section{Globalization and Latin American universities}

\author{
Everton Garcia da Costa \\ Doutorando, Universidade Federal do Rio Grande do Sul. \\ eve.garcia.costa@gmail.com
}

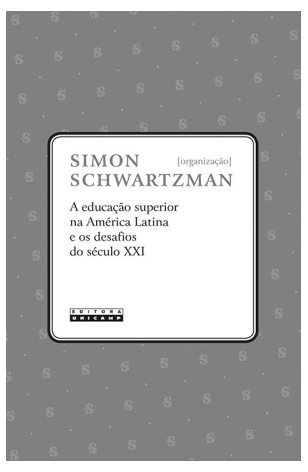

SCHWARTZMAN, Simon (Org.). A educação superior na América século XXI. Campinas: Ed. Unicamp. 2014. 286p. Latina e os desafios do

$\mathrm{O}^{\mathrm{s}}$ avanços dos processos globalizatórios trouxeram consigo um sem-número de novos desafios os quais têm incidido, em maior ou menor grau, sobre o processo de diferenciação dos sistemas sociais. No caso da educação superior, são inúmeros e multivariados os desafios que surgem paralelamente à globalização. As demandas incluem: massificação do sistema de ensino; inclusão dos grupos sociais excluídos; desenvolvimento de centros de pesquisa; criação de parcerias com investidores privados; inovação nos processos de ensino e aprendizagem por meio das novas tecnologias; contribuição para a cooperação internacional; formação ao longo da vida etc.

Compreender a natureza de algumas dessas transformações e seu impacto sobre a educação superior latino-americana é o objetivo central da coletânea A educação superior na América Latina e os desafios do século XXI. Organizada por Simon Schwartzman e publicada pela editora da Unicamp, a obra busca "entender a realidade da educação superior na América Latina hoje, e suas perspectivas para o futuro, à luz do entendimento mais geral que existe sobre o setor" (p.16).

Além de Schwartzman, o livro conta com um time de renomados pesquisadores reconhecidos internacionalmente na área de educação superior: Jamil Salmi, José Joaquín Brunner, Elizabeth Balbachevsky, Jorge Balán, Helena Sampaio, Sylvie Didou e Renato Pedrosa.

Os oito capítulos que compõem a obra abordam temas caros aos debates contemporâneos sobre educação superior na América Latina. Em geral, o livro evidencia que o cenário das universidades da região tem passado por profundas transformações ao longo das últimas quatro décadas. A principal mudança diz respeito à "expansão" dos sistemas de ensino. Os dados acerca do crescimento mostram que, em 1970, a região possuía apenas 1,9 milhão de estudantes matriculados em cursos superiores; em 1990, o número passou para 8,4 milhões; em 2011, saltou para 25 milhões.

Por um lado, essa expansão dos sistemas nacionais de ensino tem contribuído para uma melhoria na "equidade" de acesso à educação superior. As pesquisas recentes apontam que 
desde a década de 1990 tem ocorrido uma crescente inclusão dos grupos sociais historicamente excluídos da universidade. Assim, se durante muito tempo a educação superior na América Latina esteve restrita a um pequeno seguimento da população, hoje, "as oportunidades de continuar os estudos estão abertas, em princípio, a todos os estudantes que terminaram o ensino secundário" (p.107).

Por outro lado, a expansão da educação superior latino-americana está diretamente vinculada a um processo de "privatização" do ensino. No caso do Brasil, por exemplo, os dados do Censo da Educação Superior 2014 mostram que a iniciativa privada concentra 87\% das instituições de ensino superior (IES) e 75\% das matrículas de graduação (Brasil, 2015). No cenário da região, a privatização deve-se ao um conjunto de fatores: crescimento da demanda, que ultrapassa a capacidade de financiamento público; dificuldade das IES em responder de forma rápida às exigências do mercado; surgimento de uma "indústria do conhecimento", que transforma a educação em um bem rentável.

Ante o crescimento massivo da educação superior na América Latina, os governos dos países da região têm buscado desenvolver sistemas voltados para a avaliação, o reconhecimento e a acreditação dos seus sistemas de ensino. Esse é um fenômeno muito recente, só iniciado na década de 1990, e que pode ser visto como uma resposta dos governos nacionais às mudanças por que a educação superior tem passado: massificação; surgimento de provedores privados com fins lucrativos; diversificação da clientela atendida; emergência de novas carreiras profissionais; surgimento de programas de educação a distância; pressão de organismos internacionais (tais como a Organização das Nações Unidas para a Educação, a Ciência e a Cultura, a Comissão Econômica para a América Latina, o Banco Mundial, e a Organização para a Cooperação e Desenvolvimento Econômico) etc.

Como se pode observar, a globalização e o século XXI trouxeram inúmeros desafios às universidades latino-americanas. Além dos desafios já elencados, a coletânea organizada por Schwartzman destaca ainda que as universidades da região precisam lidar: com o desenvolvimento de "novas tecnologias", as quais têm revolucionado os modos de produção e transmissão do saber, as necessidades profissionais da sociedade do conhecimento e, com efeito, os sistemas de ensino superior; com a crescente "mobilidade científica", caracterizada pela migração de pesquisadores latino-americanos altamente qualificados em direção ao norte global, o que traz uma série de consequências negativas para os países da região; com a "transferência de tecnologia", elemento vital para o desenvolvimento tecnológico e econômico dos Estados nacionais.

A conclusão a que chega Schwartzman é que as IES latino-americanas não têm sabido lidar com esses desafios: "Voltadas para os seus próprios problemas do dia a dia, as instituições de ensino superior da América Latina têm muita dificuldade em entender todas essas transformações e em aprender a lidar com elas, que, no entanto, não deixam de ocorrer de forma avassaladora" (p.42).

A coletânea organizada por Schwartzman, portanto, apresenta-se como uma obra referencial àqueles pesquisadores que se dedicam à investigação da área. Muitas das transformações destacadas pelos autores, tais como a massificação, a privatização do ensino, a inclusão das camadas sociais historicamente excluídas, enfim, não se restringem apenas ao contexto da América Latina; trata-se de tendências da educação superior global, como apontam outros 
estudos, como, por exemplo, os de Altbach e Knigth (2007), Altbach, Reisberg e Rumbley (2009) e Barber, Donnelly e Rizvi (2013).

Por fim, cabe fazer uma crítica à obra. Considerando o fato de que o livro tem o objetivo de entender a realidade da educação superior latino-americana e os desafios apresentados pelo século XXI, seria fundamental dedicar um capítulo à análise dos impactos relacionados à expansão da educação a distância, modalidade de ensino que tem apresentado crescimento exponencial na região.

\section{REFERÊNCIAS}

ALTBACH, Philip; KNIGHT, Jane.

The internationalization of higher education: motivations and realities. Journal Studies in International Education, v.11, n.3-4, p.291-305. 2007.

ALTBACH, Philip; REISBERG, Liz; RUMBLEY, Laura.

Trends in global higher education: tracking an academic revolution. Paris: Unesco. 2009.
BARBER, Michael; DONNELY, Katelyn; RIZVI, Saad.

An avalanche is coming: higher education and the revolution ahead. London: IPPR. 2013.

BRASIL.

Ministério da Educação. Censo da Educação Superior 2014. Brasília: MEC/Inep. 2015. 